Tools for optimizing internal communication at the level of educational organizations. Study at the level of kindergartens in Cluj County

Luciana Truța 


\title{
Tools for optimizing internal communication at the level of educational organizations. Study at the level of kindergartens in Cluj County
}

\author{
Luciana Truța ${ }^{a^{*}}$ \\ ${ }^{a}$ Doctoral School "Education, Reflection, Development", Faculty of Psychology and Educational Sciences, Babeș-Bolyai University, Cluj-Napoca, 7 \\ Sindicatelor Street, 400029, Romania \\ *Corresponding author: lucianatruta1@gmail.com
}

\section{Abstract}

\section{Keywords:}

kindergarten; internal communication; documented procedures; optimization.
Effective communication involvement in the decision-making process of kindergarten of all members at each level of management, which leads to interactions, teamwork, exchanges of good practice, initiative. A complex tool that can be used at the level of educational organization, and that involves all levels of management, refers to the documented procedures. Am efficient communication will allow the revision of the procedures, the regulation of the institutional approaches, so that the assumed objectives and performance indicators are permanently taken into account. Thus, the purpose of the presented study aimed to establish the efficiency of documented procedures specific to managerial activities in kindergarten on the optimization of internal communication. The research involved the application of an online questionnaire that addressed the components of internal communication and documented procedures at the level of kindergartens in Cluj County. The intervention within the formative experiment, by implementing the documented procedures, had as a positive impact the highlighting, in the post-experimental stage, of some positive effects on the communication, from the perspective of the relationship with them. Documented procedures, as working tools, represent a vector for establishing and maintaining communication relations at kindergarten level, given their complexity in terms of their development and, subsequently, their implementation. The strategies used (creation of inclusive work teams, development of cooperation actions between management levels, taking responsibility for those involved by valuing their professional expertise) led to the harmonization of the manager-teacher relationship for preschool education, identifying a common vision that can be supported only by optimal internal communication.

\section{Zusammenfasung}

\section{Schlüsselworte:}

kindergarten; interne

Kommunication; dokumentierte

Verfahren; Optimierung.
Eine effiziente Kommunication beinhaltet Engagement an Entscheidungs prozess von Kindergarten, alle Mitglieder auf jeder Führungsebene, was zu Interaktionen führt, Zusammen arbeit, austausch bewürter, Initiative. Eine komplexer Arbeitweise die auf der Ebene der Bildungsorganisation eingesetzt werden kann und alle Managementebene einbeziehen, verweist auf dokumentierte Verfahren. Eine effiziente Kommunication ermöglicht die Überprüfung der Verfahren, Regulierung institutioneller Ansätze, so dass die angenommenen Ziele und Leistung indikatoren permanent in Blick zu haben. So dass, das Ziel der vorgestellten Studie, zielt darauf ab, zu etablieren die Effizien dokumentierte Verfahren speziell für die Managementtätigkeiten im Kindergarten zu ermitteln zur Optimierung der Internen Kommunication. Die Forschung umfasste die Anwendung eines Online Fragebogens, der auf die internen Kommunicationskomponenten abzielte und dokumentierte Verfahren auf der Ebene der Kindergarten aus Stadt Klausenburg. Interventionen in das Trainingsexperiment durch Implementierung dokumentierter Verfahren wirkte sich positiv aus, die Hervorhebung, in der nacherlebten Pfase, von positiver Auswikung auf die Kommunication aus der Perspektive der Beziehung zu ihnen. Dokummentierte Verfahren als Arbeitsinstrument, repräsentiert ein Vektor zum Aufbau und zur Pflege von Kommunicationsbeziehung auf Kindergartenebene, unter Berücksichtigung ihre Komplexität der Ausarbeitung und anschliepsend ihre Implementierung. Verwendete Strategien (Arbeisteams, Entwicklung von Kooperationsmapmahmen zwischen Managementebene, verantwortung für die Beteilgten übernehmen durch Wertschätzung ihrer fachtliche Expertise, feihrte zu einer Harmonisierung des Manager-Lehrer Verhältnisse für die Vorschulerziehung, Identifizierung einer gemeinsamen Vision, die aufrechterhalten werden kann, nur mit optimaler interner Kommunication.

\section{Introduction}

The kindergarten, as an educational organization, represent "a structured set of human and material resources articulated and mobilized convergently, by capitalizing of them in structured and systematic social activities, consciously aimed at achieving previously established goals, rigorously-scientifically" (RăduțTaciu, Bocoș \& Chiș, 2015, p. 37). 
Human resource, as it known, is the main factor in the development of the educational organization. The relationships yhat are established betwen the members of the educational organization, from all level of management, influence the way of achieving the established objectives. Thus, is necessary to develop harmonious communication relationships between them in order to improve all the process carroed out in kindergarten, but also "involvement and responsibility, on the one hand, as well as strategic thinking and control, on the other hand" (Pânișoară \& Manolescu, 2019, p. 45). Effetive communication at the organization level is given by the existence and observance of regulations, procedures specific to activities, applicable, not only their formal and unnecessary existence for fear of bureaucracy (Dietrich, Gavrilovici, Iosifescu, Năstase \& Niculescu, 2003).

\section{Theoretical foundation}

The efficiency of communication "reflects the very essence of educational act" (Stan, 2010, p. 115) and involves the correlation of communication methods in kindergarten, in order to optimize them. In other words, organizational communication, managerial communication and didactic communication, associated with the three levels of organizational management (management, commissions, classroom), require the identification of strategies to support their real manifestation and assumed by those involved.

The diversity of existing human resources in a kindergarten is a permanent challenge for the manager. Its role is to capitalize on the individual and group potential of the members of the organization, minimizing/eliminating the gaps between them, from the perspective of the position held, the status, seniority and location in which they operate. At the same time, the feedback provided by him encourages personal reflection, the process of regulation/selfregulation in terms of the evaluated aspect.

Effective communication involves involvement in the decision-making process of kindergarten of all members at each level of management, which leads to interactions, teamwork, exchanges of good practice, initiative. It is a good opportunity for preschool teachers to demonstrate that "teaching and daily learning practices are the main focus and everyone is responsible for the performance of that school" (Hattie, 2014, p. 305). The influence of the group can have important effects on each member, so that, through the interaction between them, they stimulate each other, each tending to capitalize on their own potential (Păuș, 2006).

An OECD study from 2013 (OECD, 2014) highlights a number of issues regarding the collaboration between teachers, but also regarding the feedback received from the members of the educational team:

- $50 \%$ state that they are rarely or never teach with colleagues;

- $2 / 3$ of the respondents did not participate in demonstration lessons of colleagues;

- 58\% did not receive feedback from a colleague;

- $46 \%$ state that they never received feedback from the principal;

- $51 \%$ say they have never received feedback from any member of the management team;

- In Romania $40 \%$ din not received feedback from the designated mentor.

A complex tool that can be used at the level of the educational organization, and that involves all levels of management, refers to the documented procedures. These "represent the specific way of carrying out an activity or a process, published on a paper or electronically" (Ordinul $n r$. 600/2018 privind aprobarea Codului controlului intern managerial al entitătilor publice, p. 11). The elaboration of the documented procedures and, subsequently, their implementation, implies the involvement of all members of the educational organization. An efficient communication will allow the revision of the procedures, the regulation of the institutional approaches, so that the assumed objectives and performance indicators are permanently taken into account.

\section{Research methodology}

The study took place between October 2020 and April 2021, at the level of kindergartens with legal personality in Cluj County. Its purpose was establish the effectiveness of documented procedures specific to managerial activities in kindergarten on optimizing internal communication.

The objectives pursued in the study:

- Implementation of documented procedures specific to managerial activities in kindergarten level; 
- Identifying the dimensions (position held, status, seniority, location of activity) that can influence the internal communication in kindergartens.

The general hypothesis of the research was formulated as follow: the use of documented procedures specific to managerial activities in kindergarten leads to the optimization of intrainstitutional communication.

The secondary hypotheses of the research were:

- There are significant differences in internal communication and documented procedures in terms of the position held;

- Seniority in office does not influence the average scores offered for the variables involved;

- The status of the respondent in kindergarten influences the answers provided for the variables involved;

- The location of the activity impacts the internal communication.

Independent research variable: use the documented procedures specific to managerial activities in kindergarten.

Dependent variable: internal communication.

During the study, 396 subjects were involved, selected on a voluntary basis, of which 40 participants (representing $10 \%$ of total) hold the positions of principal, and 356 are teachers for preschool education (representing $90 \%$ of the total); $73 \%$ of them carry out their daily activity in kindergartens with the form of legal personality organization, and the rest of the participants in kindergartens that represent their structures; $78 \%$ of participants staff have the status of incumbent (employed for an indefinite period), $21 \%$ of qualified substitute (employed for a fixed period, having studies corresponding to the position), and $1 \%$ of unskilled substitute (employed for a fixed period, without studies corresponding to the position); the most consistent age groups in the current position occupied, in terms of the volume of subjects, are the age group between 11-20 years (30\% of the total) and $0-5$ years $(25 \%$ of the total), and the lowest age group is over 25 years, with $13 \%$ of the total participants (Figure 1):
Figure 1. Brief description of the sample of subjects used in the research. Source: own processing in SPSS

Principal a Teacher for preschool education
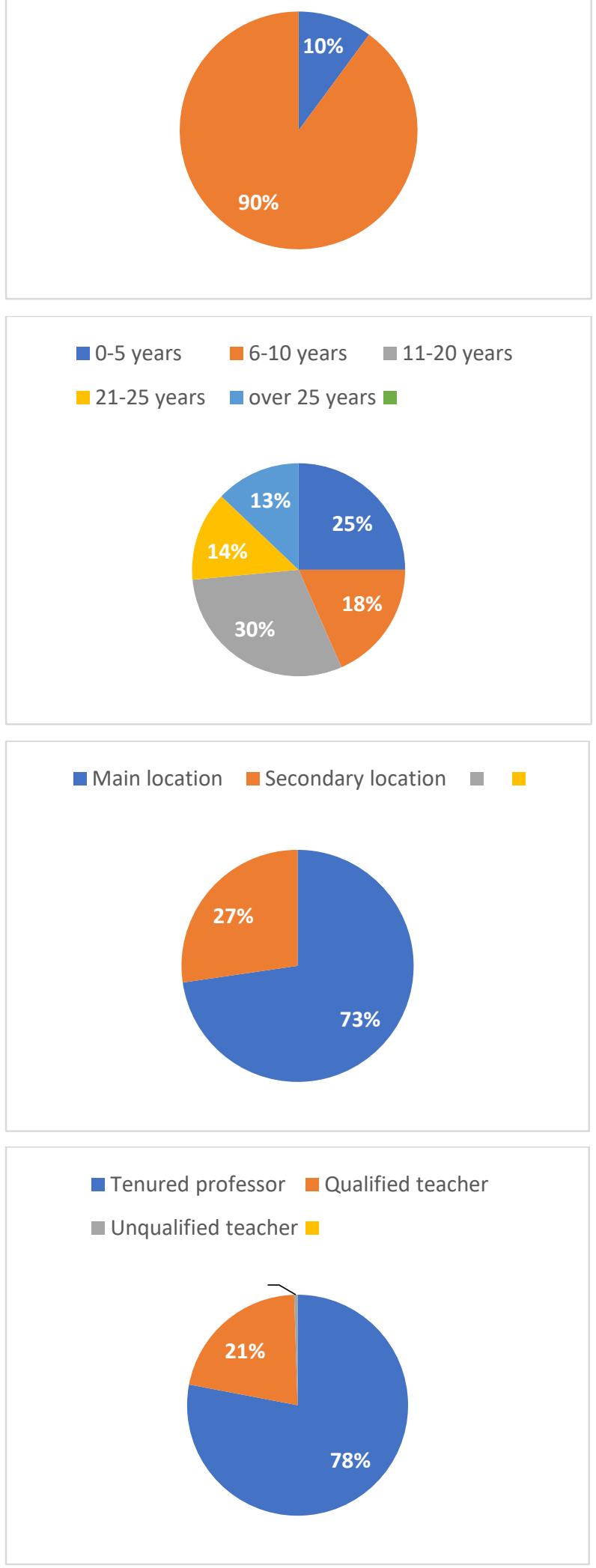

The research involved the application of an online questionnaire that addressed the components of internal communication and documented procedures 
at the kindergarten level, including seven items that aimed to:

- The efficiency of the analysis of educational practices with colleagues at the kindergarten level:

- The existence of the exchange of good practices, face to face or online, between colleagues at the kindergarten level;

- Providing feedback by the kindergarten management;

- Popularizing the performances/successes of teachers at the kindergarten level;

- The need to use documented procedures in kindergarten;

- The extent to which managerial activities are regulated by documented procedures;

- The extended to which the documented procedures specific to managerial activities are applied in kindergarten.

During the research, a series of specific methods were used, such as: the questionnaire-based survey method, the observation method, the psychopedagogical experiment. The research methodology involved processing in the SPSS statistical application of the data collected through the research tool (questionnaire), the use of principal Components Analysis (ACP) was used, descriptive analyzes, hypothesis testing, correlations variables, estimation and validation of regression models were performed.

The research design included 3 stages:

a) Pre-experimental stage: the questionnaire with items presented previously was applied; the results obtained were analyzed; documented procedures specific to managerial activities that could lead to the optimization o intra-institutional communication were developed (Table 1):

Table 1. Documented procedures delivered to kindergartens during the research

\begin{tabular}{|ll|}
\hline $\begin{array}{l}\text { Name of the documented } \\
\text { procedure }\end{array}$ & $\begin{array}{l}\text { The level of kindergarten } \\
\text { management involved }\end{array}$ \\
\hline $\begin{array}{l}\text { Operational procedure on internal } \\
\text { communication }\end{array}$ & $\begin{array}{l}\text { The level of leadership, } \\
\text { committees, and classroom }\end{array}$ \\
\hline $\begin{array}{l}\text { Operational procedure for drawing } \\
\text { up weekly group planning }\end{array}$ & $\begin{array}{l}\text { The level of leadership and } \\
\text { classroom }\end{array}$ \\
\hline $\begin{array}{l}\text { Operational procedure regarding } \\
\text { the control of school documents }\end{array}$ & $\begin{array}{l}\text { The level of leadership and } \\
\text { committees }\end{array}$ \\
\hline $\begin{array}{l}\text { Operational procedure for } \\
\text { monitoring the activity of teachers } \\
\text { through assistance }\end{array}$ & $\begin{array}{l}\text { The level of leadership and } \\
\text { classroom }\end{array}$ \\
\hline $\begin{array}{l}\text { Operational procedure for carrying } \\
\text { out inter-assistance activities at } \\
\text { unit level }\end{array}$ & $\begin{array}{l}\text { The level of leadership, } \\
\text { committees, and classroom }\end{array}$ \\
\hline $\begin{array}{l}\text { Operational procedure for } \\
\text { mentoring for novice teachers }\end{array}$ & $\begin{array}{l}\text { The level of committees and } \\
\text { classroom }\end{array}$ \\
\hline
\end{tabular}

b) The stage of formative experiment: it consisted of managerial intervention activities for the implementation of the documented procedures in the kindergarten, following:

- Creation of work teams within the commissions of the kindergarten in which to include teachers for preschool education with different statutes and age groups, to be assigned to different locations (main location and secondaries locations);

- Carrying out activities that involve each level of management in kindergarten (related to the performance indicators specific to the kindergarten);

- Valorization of teachers for preschool education with professional expertise (over 25 years old) as mentors in the exchange of good practices face to face or online at kindergarten level.

c) Post-experimental stage: the questionnaire from the pre-experimental stage was applied again, making comparisons and analyzes of the results obtained in the two stages.

\section{Results}

The interpretation of the results was made from the perspective of several dimensions that could influence the internal communication, but also the effect of implementing the documented procedures: the position held, seniority, status and location of respondents.

The analysis of the Main Components highlighted the grouping of the items in the questionnaire on two major components: internal communication and documented procedures. Analyzing the results obtained in the pre-experimental stage, we find that the most relevant item for respondents is related to the extent to which the management of the kindergarten provide feedback on their activity, and the least relevant is that subjects assess the effectiveness of analyzing educational practices with colleagues at kindergarten level (Table 2).

These findings show that, for both principals and preschool teachers, leadership feedback is extremely important and should be supported, while the item with the lowest value is at odds with other items (exchange of good practices and popularization of performance), although they fall into the same segment. The conclusion we can draw can be one that shows us that, although exchanges of good practice take place, they are not sufficiently analyzed at the level of the organization to be effective, being 
correlated with the need for feedback, validation in order to regulate the didactic approach.

Table 2. Relevance of items associated with the internal communication component. Source: own processing in SPSS

\begin{tabular}{|ll|}
\hline Associated items & Compound \\
\cline { 2 - 2 } & $\mathbf{1}$ \\
\hline $\begin{array}{l}\text { 1. To what extent does the management of the } \\
\text { kindergarten provide feedback on the activity } \\
\text { carried out in the classroom? }\end{array}$ \\
$\begin{array}{l}\text { 2. To what extent are the performances / } \\
\text { successes of the teachers popularized at the } \\
\text { kindergarten level? }\end{array}$ \\
$\begin{array}{l}\text { 3. To what extent is there an exchange of good } \\
\text { practices between colleagues face to face or online } \\
\text { (demonstrative methodological activities, inter- } \\
\text { assistance) at the kindergarten level? }\end{array}$ \\
$\begin{array}{l}\text { 4. To what extent do you consider that the analysis } \\
\text { of educational practices with colleagues at the } \\
\text { kindergarten level is effective? }\end{array}$ \\
\hline
\end{tabular}

Regarding the documented procedures component, the most relevant item for respondents shows us that specific documented procedures are applied in kindergarten, but does not consider it necessary to use them in their daily activities (Table 3):
Table 3. Relevance of items associated with the documented procedure component. Source: own processing in SPSS

\begin{tabular}{|ll|}
\hline Associated items & Compound \\
\cline { 2 - 2 } & $\mathbf{1}$ \\
\hline $\begin{array}{l}\text { 5. To what extent are the documented procedures } \\
\text { specific to the existing managerial activities applied } \\
\text { in kindergarten? }\end{array}$ & .916 \\
\hline $\begin{array}{l}\text { 6. To what extent are managerial activities regulated } \\
\text { by documented procedures? }\end{array}$ & .911 \\
\hline $\begin{array}{l}\text { 7. To what extent do you consider it necessary to } \\
\text { use in kindergarten the documented procedures } \\
\text { aimed at the management of learning activities? }\end{array}$ & .648 \\
\hline
\end{tabular}

The conclusion that emerges from this analysis can be related to the fact that the members of the educational organization do not understand the role of the documented procedures in regulating the functioning of the institution, being necessary their involvement in the elaboration and revision of all procedures.

Comparing the two components, from the perspective of the function held by the respondents and the scores given, it is highlighted that the scores given by preschool teachers for the documented procedures component are higher than in the case of principals, while for the internal communication component the situation changes, the principals giving higher scores, being small differences between them. (Figure 2):

Figure 2. Central trend indicators based on the function held in kindergarten. Source: own processing in SPSS

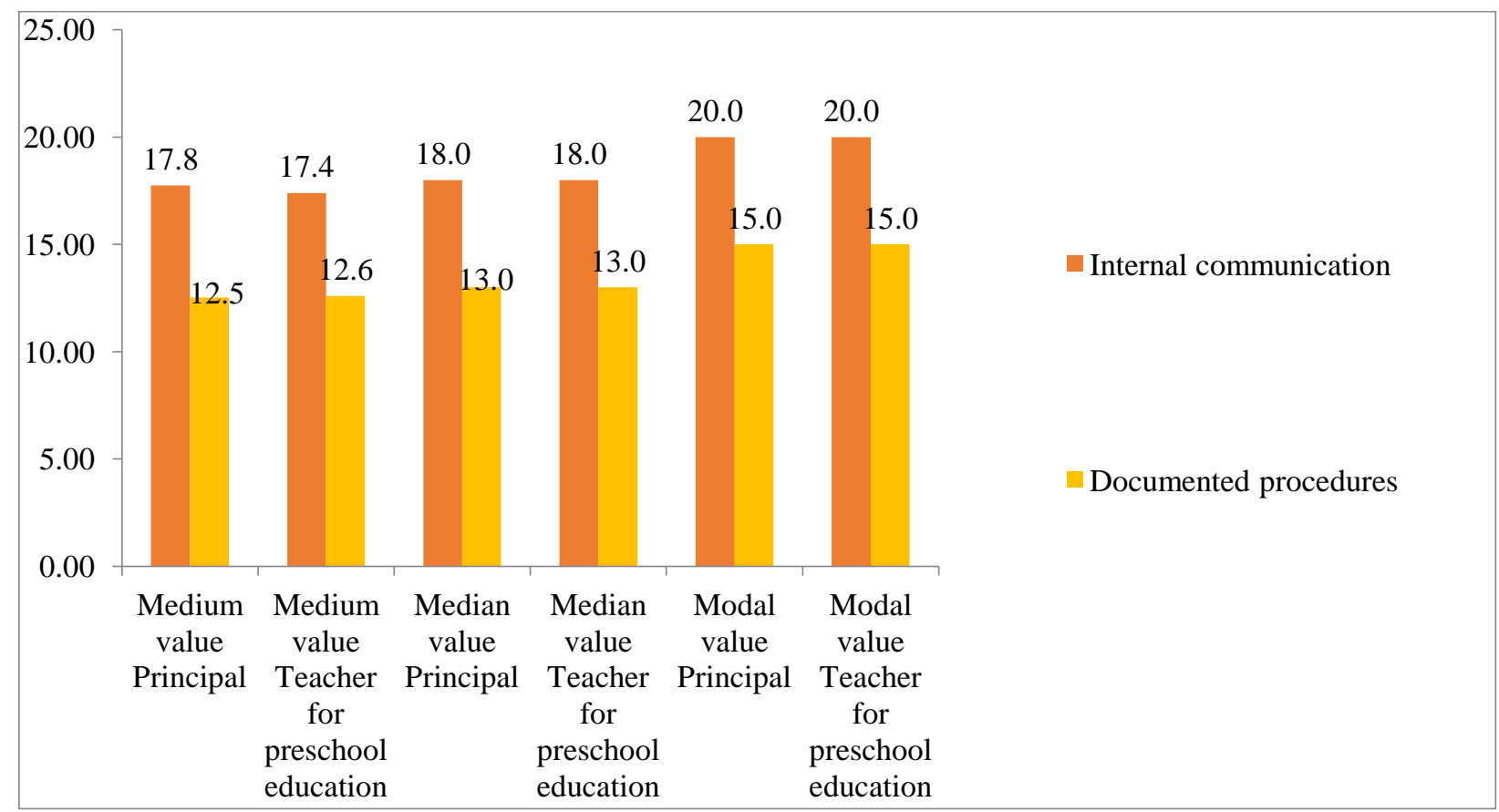

Even if the differences highlighted are not large, it is necessary to have another perspective, apart from that of the position held by the respondents. Each, in turn, consciously, relates to one or more levels of management in kindergarten. Thus, even more, it is necessary to optimize the internal communication, considering the various roles assumed by the members of the organization at a time. 
Table 4. Indicators of the central tendency based on seniority according to the position held in kindergarten. Source: own processing in SPSS

\begin{tabular}{|c|c|c|c|}
\hline \multicolumn{2}{|c|}{ Seniority of respondents } & \multirow{2}{*}{$\begin{array}{l}\begin{array}{l}\text { Internal } \\
\text { communication }\end{array} \\
17.4\end{array}$} & \multirow{2}{*}{$\begin{array}{l}\text { Documented } \\
\text { procedures }\end{array}$} \\
\hline \multirow{5}{*}{$\begin{array}{l}\text { Medium } \\
\text { value }\end{array}$} & $0-5$ years old & & \\
\hline & $6-10$ years old & 17.73 & 12.73 \\
\hline & $11-20$ years old & 17.27 & 12.28 \\
\hline & $21-25$ years old & 17 & 12.3 \\
\hline & over 25 years old & 17.82 & 13.2 \\
\hline \multirow{5}{*}{$\begin{array}{l}\text { Median } \\
\text { value }\end{array}$} & $0-5$ years old & 18 & 13 \\
\hline & $6-10$ years old & 18 & 13 \\
\hline & $11-20$ years old & 18 & 12 \\
\hline & $21-25$ years old & 17 & 12 \\
\hline & over 25 years old & 18 & 14 \\
\hline
\end{tabular}

Regarding the seniority of the respondents, we can say that teachers for preschool education older than 25 years have higher average scores than the other age

Figure 3. Central trend indicators based on the location where the daily activity takes place. Source: own processing in SPSS

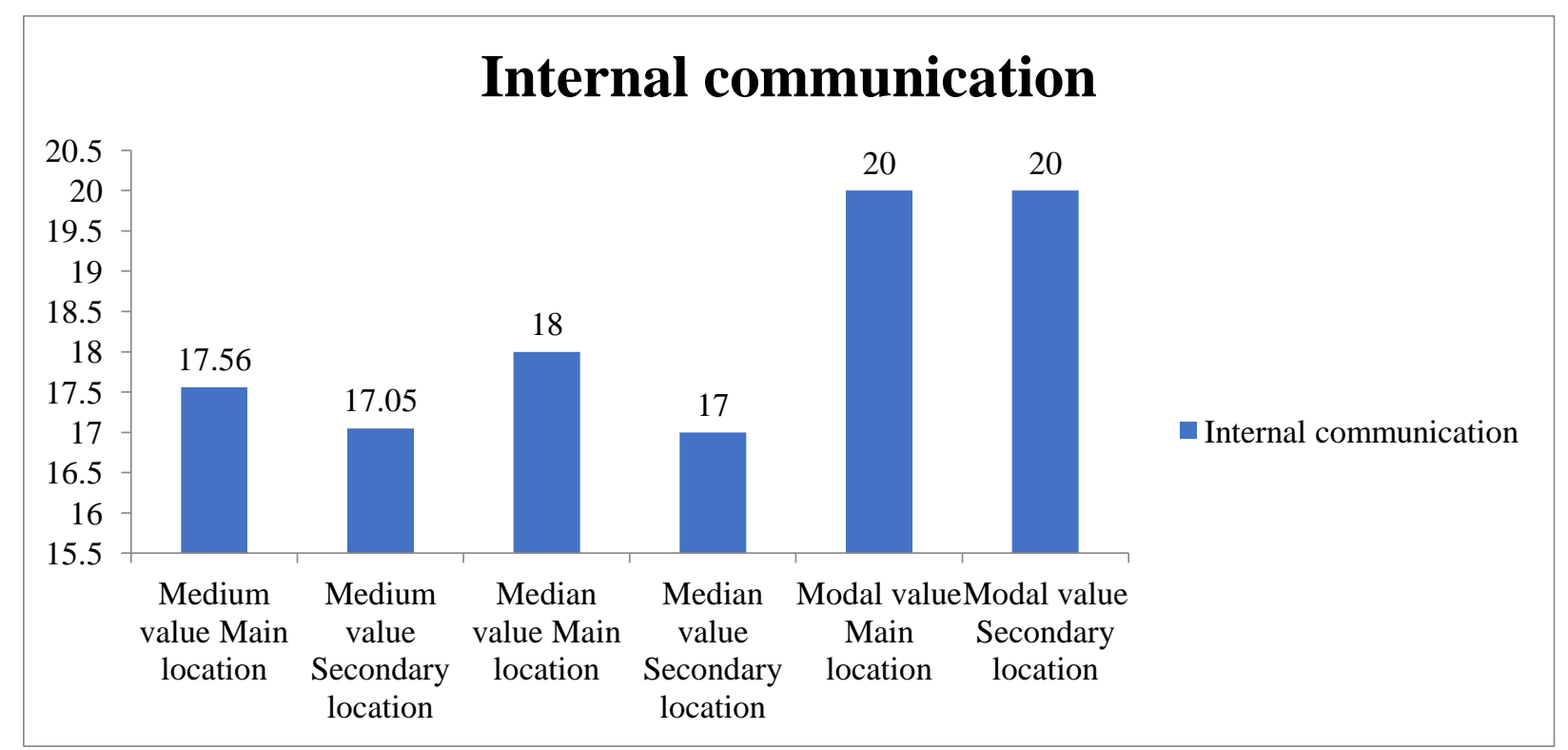

Figure 4. Indicators of the central tendency on the status of the respondent in kindergarten. Source: own processing in SPSS

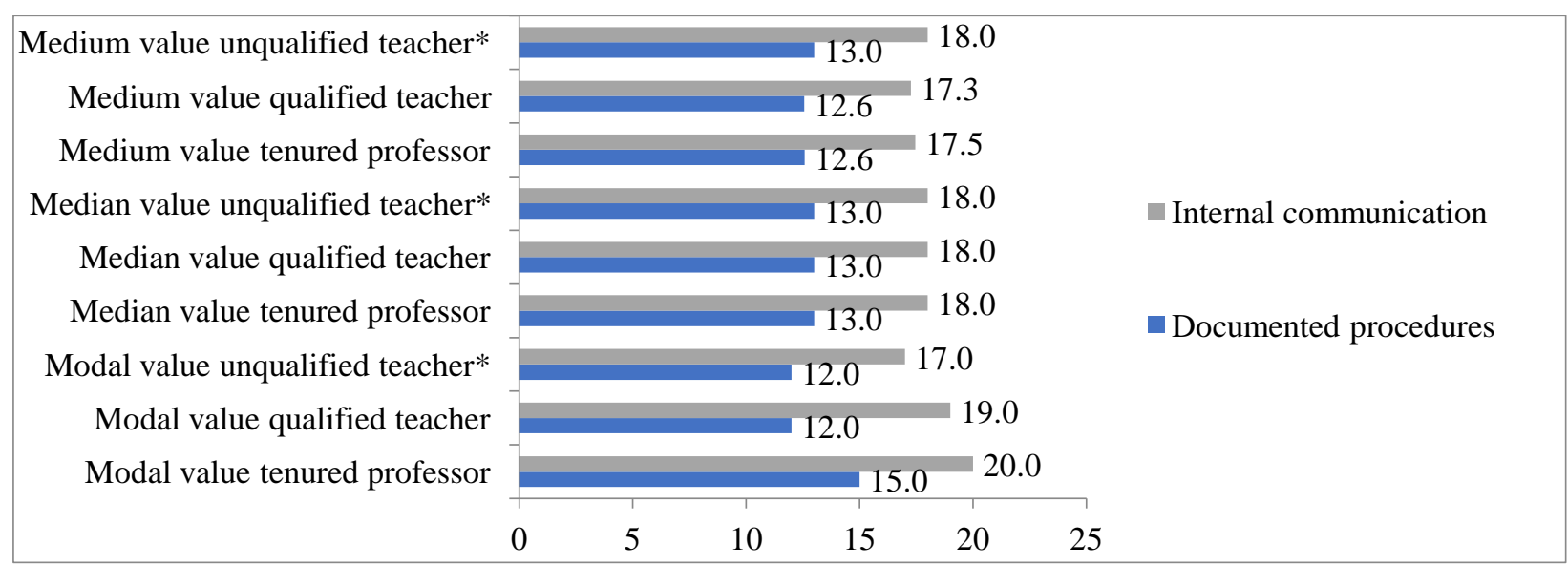

groups involved in the study for both components analyzed. We also draw attention to the slightly lower scores given both for internal communication and for procedures documented by those who fall into the 21 25 years old group, although it is a listed segment with professional expertise (table 4).

We can assume that, for the 21-25 age segment, receiving feedback and the efficiency of the analysis of educational practices can influence the perspective on documented procedures and internal communication.

It is necessary, therefore, to enhance the expertise of teachers for preschool education with over 25 years of experience in the training experiment. Regarding the location of the subjects' activity, the internal communication component was analyzed, resulting in the fact that those in the main location have higher scores than those who work at the structures (Figure $3)$ : 
It follows that, in the main location, the organizational and managerial communication are more intense than at the level of structures. Regarding the didactic communication, we cannot comment.

It is therefore necessary to intensify the cooperation relations between the locations in the formative experiment stage, by identifying appropiate strategies. Compared to the status of the subjects, the average scores given by the unqualified substitutes, compared to the incumbents and qualified substitutes, are higher for both components analyzed (Figure 4).

The median value is identical for the three types of status included in the analysis in the case of internal communication and documented procedures, so it can be stated that the distribution of scores by median is the same for these two variables, regardless of the status of the reporting teacher. The conclusions of the pre-experimental stage regarding the formulated hypotheses are the following:

- The secondary assumption that there are significant differences in internal communication and documented procedures in terms of the position held is not validated at this stage;

- The secondary hypothesis seniority in office does not influence the average scores offfered for the variables involved is not validated for the age groups 21-25 years and over 25 years and only for the variable

Figure 5. Central tendency indicators based on the function held in kindergarten in the post-experimental stage. Source: own processing in SPSS

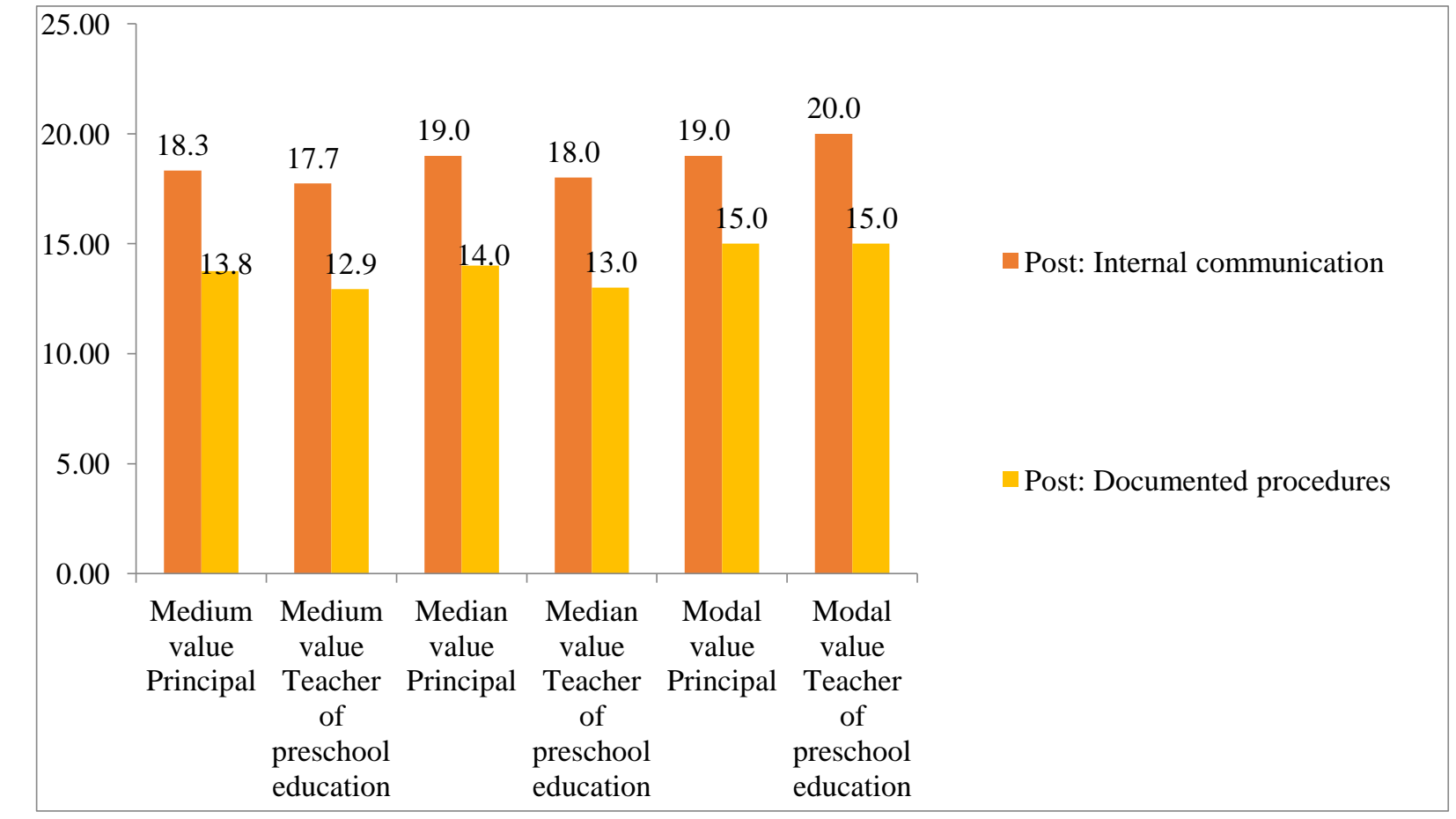

If in the pre-experimental stage, teachers for preschool education gave higher scores to the documented procedures for the intervals 11-20 years and over 25 years;

- The secondary hypothesis regarding the fact that the status of the teacher in kindergarten influences the answers provided for the variables involved is not validated at this atsge of the research;

- The secondary hypothesis regarding the fact that location of the activity impacts the internal communication is validated for this stage.

Regarding the general hypothesis, the use of documented procedures specific to managerial activities in kindergarten leads to the optimization of intra-institutional communication, it is also validated by the existence of a statistically significant direct link, of medium intensity (Table 5). Thus, if the scores of the documented procedures will increase, the same will happen with the scores of internal communication.

Table 5. Correlations between internal communication and documented procedures, pre-experimental stage

\begin{tabular}{|lr|}
\hline \multicolumn{2}{|c|}{ Documented procedures } \\
\hline Internal communication & $.566 * * *$ \\
$* * *$ significant at the significance threshold of $0.1 \%$
\end{tabular}

After completing the training experiment, the postexperimental stage took place, applying, again, the initial questionnaire. documented procedures, compared to principals, in the post-experimental stage they gave lower scores than 
the principals of both variables analyzed (documented procedures, internal communication), according to figure 5. This change in the scores associated with the two categories of respondents may result from streamlining managerial activity through the use of procedures documented by principals, and this may seem too rigorous for teachers for preschool education. Or, another perspective may be that the principal uses documented procedures at the level of all departments in the kindergarten, and the regulatory impact, felt by him, is much stronger. The increase in average scores for the internal communucation variable is 0.5 points for principals and 0.3 points for preschool teachers. The variable documented procedures registered an increase of 1.3 points from the principals (average score), and for teachers of 0.3 points. This aspect is also reinforced by the fact that the median value for the documented procedures variable is the same for teachers for preschool education in both stage analyzed. In contrast, the median value for the same variable, associated with the principals, increased by one point in the postexperimental stage.

The size of seniority in office shows average values of approximately equal scores regarding the internal communication variable, with the mention that the subjects included in the seniority group over 25 years are associated with the highest average values, as in the case of the documented procedures variable. A significant jump in terms of documented procedures is shown by the average scores for the 1120 year old group, which increased compared to the initial stage from 12.28 pointsto 13.08 points. At the same time, the median values for the groups of 11-20 years and over 25 years are the highest, supporting the average values identified. For the internal communication variable, the median values are identical for all age groups analyzed in this stage, with the group 21-25 years registering an increase of one point compared to the pre-experimental stage (Table $6)$. It is important that the highest value increases are found in the 11-20 and 21-25 age segments, covering a percentage of $44 \%$ of respondents. Certainly, the area of influence of the respondents with more that 11 years of experience (57\%) will subsequently determine significant value increases in the 0-10 age segment, both in terms of internal communication and in terms of perception on documented procedures.
Table 6. Central tendency indicators based on seniority in kindergarten, post-experimental stage. Source: own processing in SPSS

\begin{tabular}{|llll|}
\hline Seniority of respondents & $\begin{array}{l}\text { Post: Internal } \\
\text { communication }\end{array}$ & $\begin{array}{l}\text { Post: } \\
\text { Documented } \\
\text { procedures }\end{array}$ \\
\hline \multirow{4}{*}{$\begin{array}{l}\text { Medium } \\
\text { value }\end{array}$} & 0-5 years old & 17.95 & 12.90 \\
\cline { 2 - 4 } & 6-10 years old & 17.68 & 12.97 \\
\cline { 2 - 4 } & 11-20 years old & 17.89 & 13.08 \\
\cline { 2 - 4 } & over 25 years old & 17.92 & 12.81 \\
\cline { 2 - 4 } Median years old & 17.37 & 13.41 \\
\cline { 2 - 4 } value & 6-10 years old & 18 & 13 \\
\cline { 2 - 4 } & 11-20 years old & 18 & 13 \\
\cline { 2 - 4 } & 21-25 years old & 18 & 14 \\
\hline
\end{tabular}

Regarding the location of the activity, the average value of the scores is higher for the respondents from the main location than for the structures, a situation identical to that of the pre-experimental stage (Figure $6)$.

Figure 6. Indicators of the central tendency based on the location of daily activity, the post-experimental stage. Source: own processing in SPSS

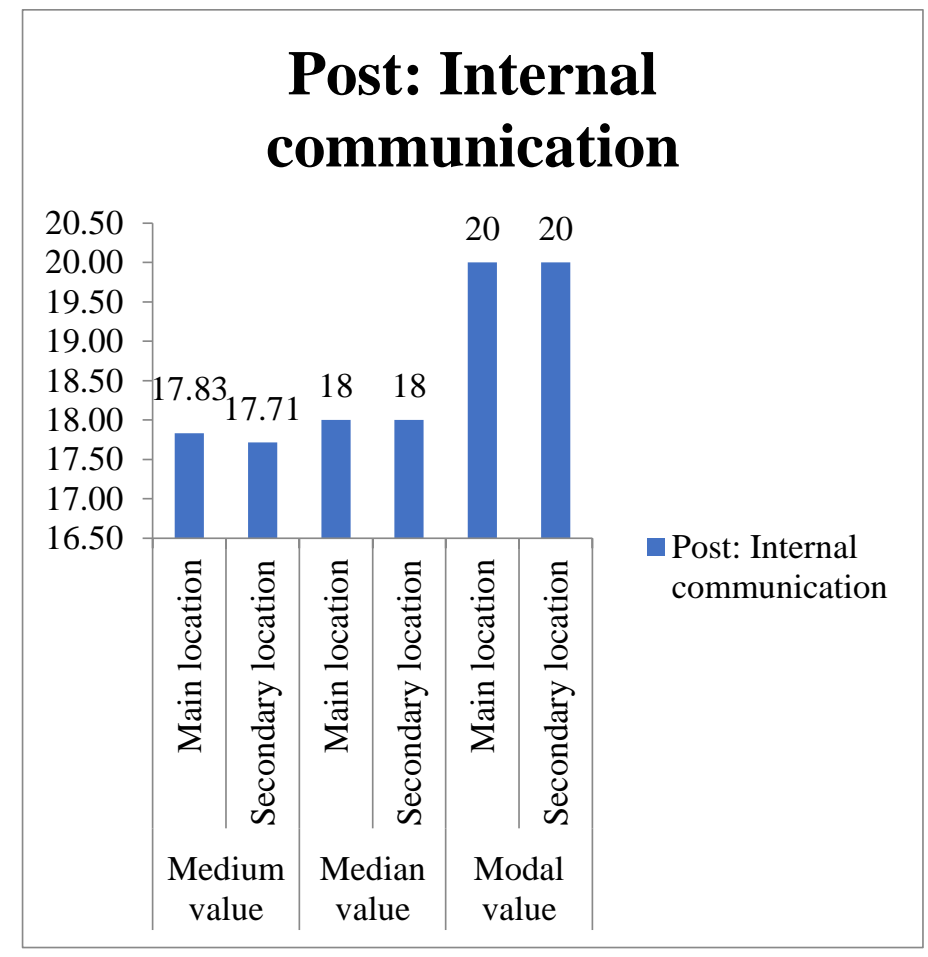

Identical to the pre-experimental stage, the average scores given by unqualified substitutes are higher than those given by holders and qualified substitutes for both variables analyzed. Given the uncertain status of unqualified substitutes, we will highlight the differences between the twi stages for incumbents and qualified substitutes. Thus, the average values of the 
scores associated with the internal communication variable increased slightly compared to the preexperimental stage for both selected statuses. Regarding the veriable documented procedures, an inscrease of 0.5 points is registered in the right of the holders, for the qualified substitutes remaining the same values as in the pre-experimental stage. This fact can be explained by the motivation of the incumbents to assume the implementation of the documented procedures (being employed for an indefinite period), while the qualified substitutes are employed for a determined period, without stability in kindergarten. Staff mobility can be a disruptive factor in achieving effective internal communication, but also in implementig procedures, lacking continuity in activity. The median values are identical to those in the initial stages, some higher being recorded only in unqualified substitutes (Figure 7).

Figure 7. Indicators of the central tendency on the status of the respondent in kindergarten, the post-experimental stage. Source: own processing in SPSS

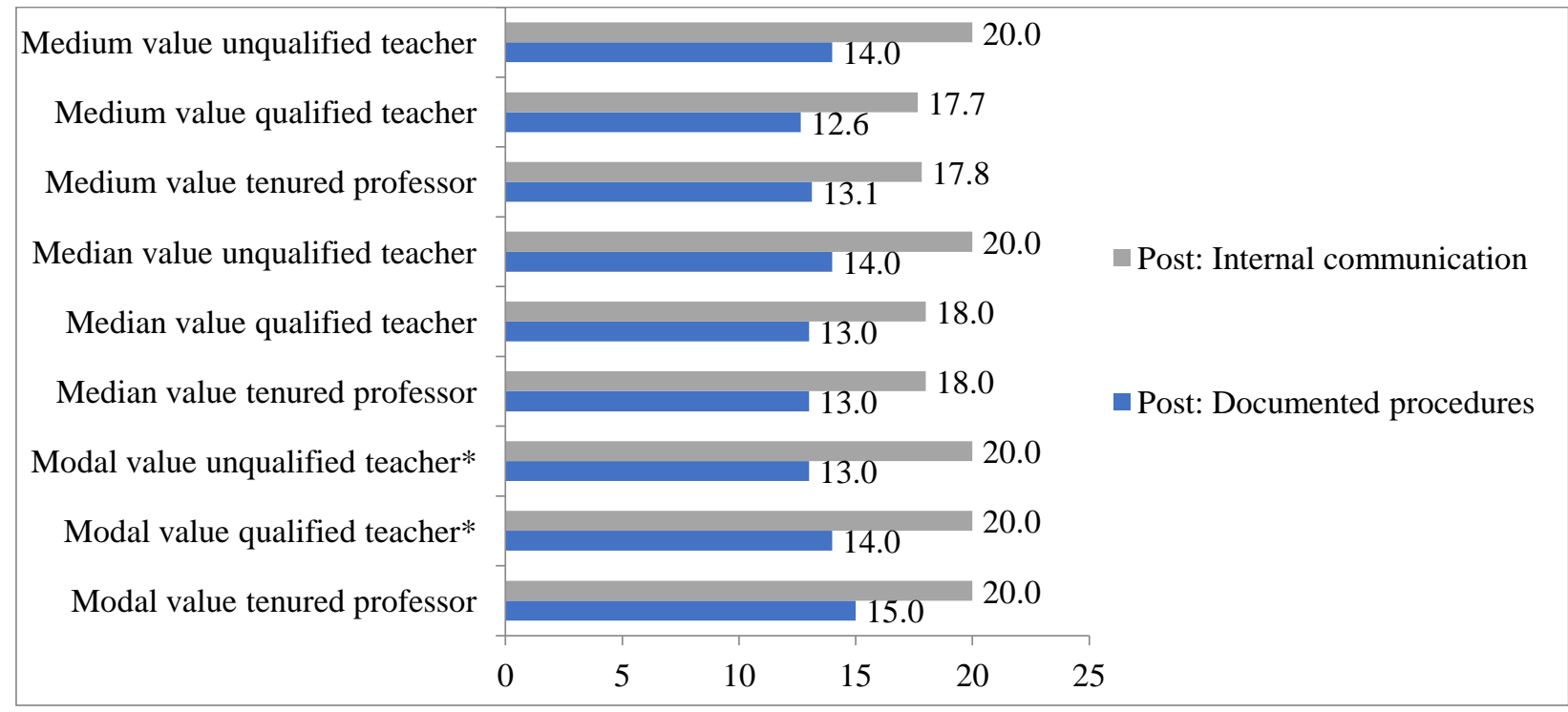

The conclusions of the post-experimental stage regarding the formulated hypotheses are the following:

- The secondary assumption that there are significant differences in internal communication and documented procedures, from the point of view of the position held, is validated at this stage only in the case of documented procedures;

- The secondary hypothesis, the seniority in office does not influence the average scores offered for the variables involved, it is validated for all the analyzed seniority group;

- The secondary hypothesis regarding the fact the status of the teacher in kindergarten influences the answers provided for the variables involved is validated for the research variable documented procedures;

- The secondary hypothesis regarding the fact that the location of the activity impacts the internal communication is not validated at this stage.

Regarding the general hypothesis, the use of documented procedures specific to managerial activities in kindergarten leads to the optimization of intra-institutional communication, it is also validated by the existence of a statistically significant direct link, of medium intensity (Table 7). Thus, if the scores of the documented procedures will inscrease, the same will happen with the scores of internal communication. It can be seen that we have a higher correlation coefficient thar that obtained in the preexperimental stage, as shown in Table 7:

Table 7. Correlations between internal communication and documented procedures, post-experimental stage. Source: own processing in SPSS

\begin{tabular}{|c|c|}
\hline & Post: Documented procedures \\
\hline Post: Internal communication & $.631^{* *}$ \\
\hline
\end{tabular}

\section{Discussions}

Correlating the answers regarding the importance of the feed-back on the activities carried out with those regarding the inefficiency of analysis of educational practices with colleagues, but also with the minimization of the role of documented procedures, we consider that actions are required to enhance the role of feed-back at the kindergarten level. In this sense, communication between the three levels of 
management can be improved by developing clear documented procedures, so as to concretely regulate the methods, tools, responsible human resources, periodicity and effective means of communication.

\section{Conclusions}

The intervention within formative experiment, by implementing the documented procedures, had a positive impact the highlighting, in the postexperimental stage, of some positive effects on the communication, from the perspective of the relationship with them. Documented procedures, as working tools, represent a vector for establishing and maintaining communication relations at kindergarten level, given their complexity in terms of their development and, subsequently, their implementation. By facilitating communication at the horizontal level (at management level), but also in a vertical, hierarchical sense (between levels), the manager created a tool managed to reduce the communication gaps between them. The strategies used (creation of inclusive work team, development of cooperation actions between management levels, taking responsibility for those involved by enhancing their professional expertise) led to the harmonization of the manager-teacher relationship for preschool education, identifying a common vision that can be supported only by optimal internal communication.

\section{Authors note:}

Luciana Truța is associate teacher at the Department of Educational Sciences, Babeș-Bolyai
University, Cluj-Napoca. She has a degree in educational science and her fields of interest include: class management, institutional management, efficient methods of institutional communication and identifying procedures for streamlining the functionality of the kindergarten.

\section{References}

Dietrich, M., Gavrilovici, O., Iosifescu, Ș., Năstase, M., \& Niculescu, R.M. (2003). Management educaţional volumul I. Iași: CDRMO Publishing House.

Hattie, J. (2014). Învăţarea vizibilă: ghid pentru profesori. (C. Dumitru, traducător). București: Trei Publishing House. (Lucrarea inițială apărută în 2012).

OECD (2014). TALIS 2013 Results: An International Perspective on Teaching and Learning. OECD Publishing. https://dx.doi.org/10.1787/9789264196261en.

Ordinul nr. 600/2018 privind aprobarea Codului controlului intern managerial al entităţilor publice. Monitorul Oficial al României, Partea I, nr. 387 din 07 mai 2018.

Pânişoară, I.-O., \& Manolescu, M. (coord.) (2019). Pedagogia învățământului primar și preșcolar - volumul I. Iași: Polirom Publishing House.

Păuș, V.A., (2006). Comunicare și resurse umane. Iași: Polirom Publishing House.

Răduț-Taciu, R., Bocoș, M., \& Chiș, O. (coord.) (2015). Tratat de management educațional pentru învățământul primar și preșcolar. Pitești: Paralela 45 Publishing House.

Stan, C. (2010). Perspective teoretic-aplicative în abordarea obstacolelor din comunicarea didactică. ClujNapoca: Eikon Publishing House. 